\title{
Experimental investigation of mechanical properties of sisal fiber and rice husk reinforced polymer composite
}

\author{
Madhusudhana Reddy $\mathrm{H}^{1}$, Bharath S Kodli ${ }^{2}$, Ravi B Chikmeti ${ }^{3}$ \\ ${ }^{I}$ M.Tech. (Student), Mechanical Engineering Department, PDA College of Engineering, Gulbarga, Karnataka, \\ India \\ ${ }^{2}$ Professor, Mechanical Engineering Department, PDA College of Engineering Gulbarga, Karnataka, India \\ ${ }^{3}$ Tool \& Die Maker, Govt. Tool Room and Training Centre Bangalore, Karnataka, India
}

\begin{abstract}
In this research, sisal fiber as the major reinforcement and rice husk as an additional fiber to improve the mechanical property of polymer composite with resin ECMALON 4413 as the base material prepared by hand layup process according to ASTM standards. Test specimens are prepared with different \% weight of sisal fiber and a small percentage of rice husks are added and tests were conducted. Thus, improvement in mechanical properties of the hybrid composite material is observed. With the SEM analysis the conclusion of the project is made for compatibility of sisal and rice husk with Resin ECMALON 4413 and the interfacial bonding between matrix and reinforcement is observed.
\end{abstract}

Keywords: Resin ECMALON 4413, Rice Husk, Sisal, Tensile strength, Flexural strength and Hardness.

\section{Introduction}

The use of natural filler for the reinforcement of the composites has received increasing attention both by the academic sector and the industry. Natural filler have many significant advantages over synthetic filler and fibres such as their light-weight, low cost, ability to reduce abrasion of machinery and also non-toxicity. Other than that, rice husks as fillers have advantages over mineral fillers, as they are non-abrasive, require less energy for processing and ability to reduce the density of furnished products. Hence, these composites have attracted much attention, and are becoming increasingly important for the production of a wide variety of cheap lightweight environment friendly composites [1].Increasing concern about global warming and depleting petroleum reserves have made scientists to focus more on the use of natural fibres such as bagasse, coir, sisal, jute etc. This has resulted in creation of more awareness about the use of natural fibres based materials mainly composites. In past decade there has been many efforts to develop composites to replace the petroleum and other non decaying materials based products. The abundant availability of natural fibre in India gives attention on the development of natural fibre composites primarily to explore value-added application avenues. Reinforcement with natural fibre in composites has recently gained attention due to low cost, easy availability, low density, acceptable specific properties, ease of separation, enhanced energy recovery, $\mathrm{C} 02$ neutrality, biodegradability and recyclable in nature [2]. The present research work is more interested in preparing a composite made of natural fiber as they are abundantly available and cheaper compare to synthetic fiber which need to processed and made-up of chemicals to gain the required property of a composite. The most common natural fibers are Coir, Rice Husk, Jute, Hemp etc. all these natural fibers yield better mechanical strength added with thermoset and thermoplastics. Polymer matrix composites are gaining more importance compare to monolithical materials as being more reliable and cheaply available. Polymer matrix composites finding application from household to engineering approach. With the advancement of PMC's their properties have been increased by one the addition of one more fiber made as hybrid composite which boost the property of PMC where a single fiber composite lags [3]. Water absorption test was conducted and the results showed that the composites absorb more water as the weight percentage of RH increased, which attributed to the ability of RH fillers to absorb water. In this study, rice husks filler polyester composites were produced with rice husks (RH) as filler and unsaturated polyester resin (UPR) as the matrix. Several percentages of filler loadings were used $(10,15,20$ and $25 \mathrm{wt} \%)$ in order to gain insights into the effect of filler content on the mechanical properties and water intake of the composites. From the results, the tensile strength of the RH filled UPR composites found to be decrease as the filler loading increase [4]. Natural fibers have been used to reinforcing materials for over 2,000 years. The necessity for renewable fiber reinforced composites has not been as prevalent as it currently is. Natural fibers are emerging as cost effective and apparently ecologically superior substitutes to glass fibers in composites. In this review a comparative life cycle valuation of Natural fiber reinforced polymer matrix composite materials has been accounted. The methodology and findings of mechanical and fracture surface characterization of various natural fiber composites has been summarized. The use of Natural fibre as reinforcement in polymer based composites were reviewed from viewpoints of position and future expectations of natural bio-fibres, construction and properties of natural fibre, fibre surface modifications, and physical and mechanical 
characteristics of natural fibre based polymer composites. Natural fibres have good prospective as reinforcements in polymers (thermoplastics, thermosets and elastomers) composites. Due to the high specific properties and low density of natural fibres, composites based on these fibres may have very good implications in industry. Moreover, reduced abrasion and consequent reduction of re-tooling makes these composites one of the most effective alternatives. The natural fibres as a source of raw material in polymer industry not only provides a renewable resource, but could also produce a source of economic development for rural areas [5].

\section{A. Materials}

\section{Materials And Processing}

The materials used in the present research work are tabulated in Table I with their properties and suppliers.

Table 1: Specifications of the Materials

\begin{tabular}{|c|c|}
\hline Materials & Specification \\
\hline $\begin{array}{l}\text { Unsaturated polyester resin } \\
\text { ECMOLAN } \mathbf{4 4 1 3}\end{array}$ & $\begin{array}{l}\text { Density: } 1.13 \mathrm{~g} / \mathrm{cm}^{3} \\
\text { UTS: } 50 \mathrm{MPa} \\
\text { Flexural Strength: } 85 \mathrm{MPa} \\
\text { Heat distortion temperature: } 70{ }^{0} \mathrm{C}\end{array}$ \\
\hline Sisal fiber & $\begin{array}{l}\text { Bulk density : } 1.450 \mathrm{~g} / \mathrm{cm}^{3} \\
\text { Chopped length: } 50-80 \mathrm{~mm} \\
\text { Diameter: } 100-300 \mu \mathrm{m}\end{array}$ \\
\hline Rice Husk & $\begin{array}{l}\text { Bulk density :70- } 80 \mathrm{~g} / \mathrm{cm}^{3} \\
\text { length : } 3-6 \mathrm{~mm}\end{array}$ \\
\hline $\begin{array}{l}\text { Cobalt } \\
\text { (Accelerator) }\end{array}$ & Density: $0.98 \mathrm{~g} / \mathrm{cm}^{3}$ \\
\hline $\begin{array}{l}\text { Methyl Ethyl Ketone } \\
\text { peroxide (MEKP) Catalyst }\end{array}$ & Density: $1.17 \mathrm{~g} / \mathrm{cm}^{3}$ \\
\hline Glass fiber Sheet & Thickness: $100 \mu \mathrm{m}$ \\
\hline
\end{tabular}

\section{B. Processing of Sisal fiber, Rice Husk \& Unsaturated polyester resin Composite}

Composite is prepared first to know at what percentage of weight fraction the composite gives the Ultimate

Tensile Strength from that percentage some percentage of Rice Husk is added to enhance its tensile property. First make some sample preparation calculation before preparing the composite as given below and start the fabrication by preparing the temporary mould using beadings arranged on the granite base representing a rectangular mould of $250 \mathrm{~mm} \times 25 \mathrm{~mm} \times 10 \mathrm{~mm}$ is shown in figure 1. Pour the calculated amount of resin with thoroughly mixed Promoters, Accelerators \& Catalyst of $1 \%$ to the UPS and wait for ten minutes so that it starts pre hardening then put a Glass fiber sheet on to it and then apply pressure by placing a concrete block over the setup for 24 hours to complete cure the laminate and once the laminate is completely cured then it"s ready for machining according to ASTM standard for testing, repeat the procedure by adding $0,5,10,15,20 \%$ wt of sisal fiber to the resin. At optimum percentage then add 1,3, and 5\% of Rice Husk and repeat the same procedure to get the Hybrid composite and is tested for mechanical properties. Composite with \% wt fiber prepared using Hand layup procedure.

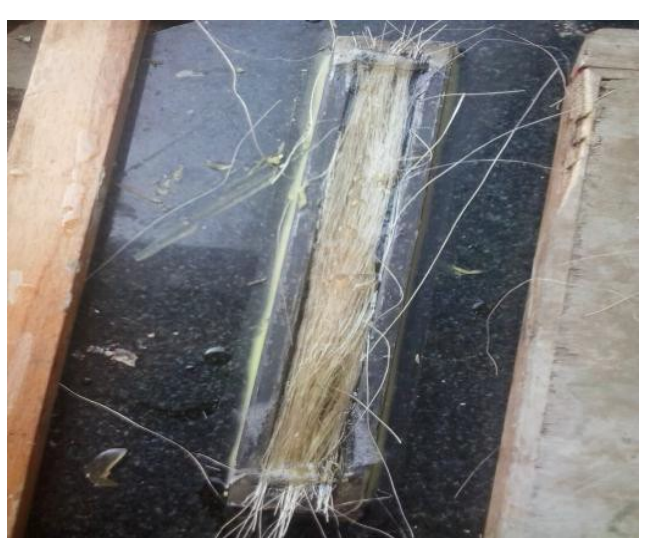

Figure 1: Rectangular mold

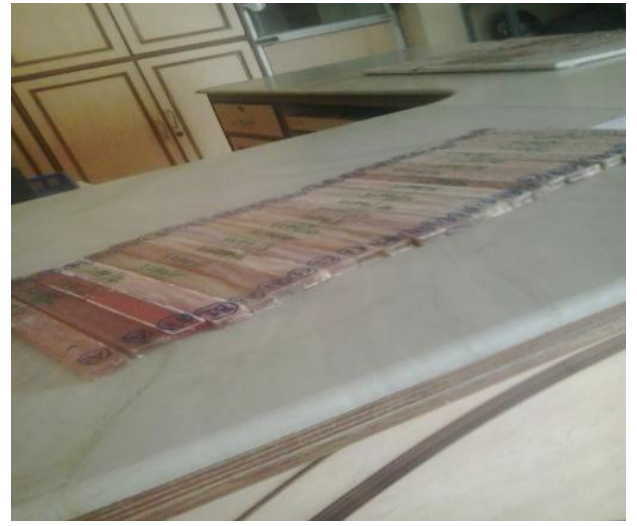

Figure 2: Specimens 


\section{Sample Preparation}

Composite laminate of $250 \mathrm{~mm}$ X $25 \mathrm{~mm}$ X $10 \mathrm{~mm}$ were fabricated

Density of Unsaturated polyester resin $(\delta)=1.13 \mathrm{~g} / \mathrm{cm}^{3}$

Volume of the mold $(\mathrm{V})=250 \mathrm{~mm} \times 25 \mathrm{~mm} \times 10 \mathrm{~mm}=62500 \mathrm{~mm}^{3}$

Mass of resin $(\mathrm{m})=$ Volume of mould $\mathrm{x}$ Density of Unsaturated polyester resin $=62.5 \times 1.13=70.62 \mathrm{~g}$

Table 2: \% wt of sisal fiber and UPS

\begin{tabular}{|l|l|l|l|l|l|}
\hline Samples & $\begin{array}{l}\text { \% Wt of Sisal Fiber } \\
(\mathrm{gms})\end{array}$ & $\begin{array}{l}\text { \% of Unsaturated } \\
\text { polyester resin } \\
(\mathrm{gms})\end{array}$ & $\begin{array}{l}\text { Mass of sisal Fiber } \\
(\mathrm{gms})\end{array}$ & $\begin{array}{l}\text { Mass of Unsaturated } \\
\text { polyester resin }\end{array}$ & $\begin{array}{l}\text { Total Mass } \\
(\mathrm{gms})\end{array}$ \\
\hline $\mathrm{A}$ & 0 & 100 & 0 & 70.62 & 70.62 \\
\hline $\mathrm{B}$ & 5 & 95 & 3.53 & 67.09 & 70.62 \\
\hline C & 10 & 90 & 7.06 & 63.56 & 70.62 \\
\hline D & 15 & 85 & 10.59 & 60.03 & 70.62 \\
\hline E & 20 & 80 & 14.12 & 56.50 & 70.62 \\
\hline
\end{tabular}

Table 3: $\%$ wt of sisal fiber, UPS and rice husk

\begin{tabular}{|l|l|l|l|l|l|}
\hline Samples & $\begin{array}{l}\text { \% Wt of Sisal } \\
\text { Fiber }\end{array}$ & $\begin{array}{l}\text { \% of Unsaturated } \\
\text { polyester resin }\end{array}$ & \%Wt of Rice Husk & $\begin{array}{l}\text { Mass of Unsaturated } \\
\text { polyester resin } \\
\text { (gms) }\end{array}$ & $\begin{array}{l}\text { Total Mass } \\
\text { (gms) }\end{array}$ \\
\hline F & 19 & 80 & 1 & 56.49 & 70.62 \\
\hline G & 17 & 80 & 3 & 56.49 & 70.62 \\
\hline H & 15 & 80 & 5 & 56.49 & 70.62 \\
\hline
\end{tabular}

The above samples are tested for mechanical properties that are tensile and flexural strength according ASTM standards.

\section{Mechanical Characterisation}

Composite materials were subjected to various mechanical tests to measure strength, elastic constants, and other material properties. The results of such tests were used for two primary purposes: 1) engineering design (for example, failure theories based on strength, or deflections based on elastic constants and component geometry) and 2) quality control either by the materials producer to verify the process or by the end user to confirm the material specifications. A Universal Testing Machine (UTM) is an instrument used for the measurement of loads and the associated test specimen deflections such as those encountered in tensile, compression or flexural modes. It is used to test the tensile, flexural properties of materials. Load cells and extensometers measure the key parameters of force and deformation as the sample was tested [3].

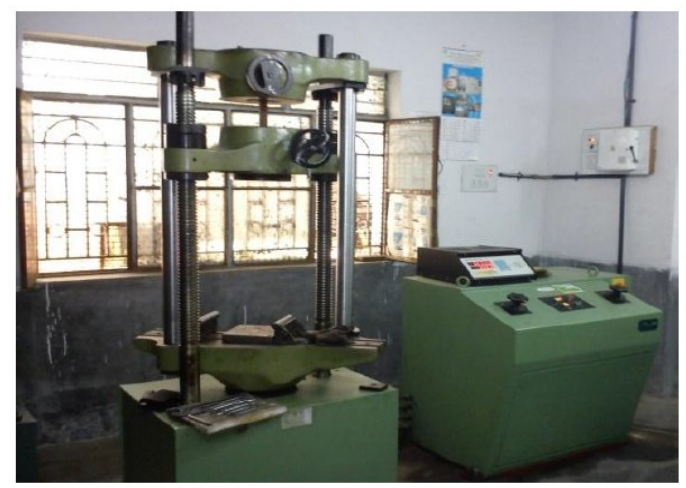

Figure 1: Universal Testing Machine

\section{Ultimate Tensile Strength}

Ultimate tensile strength, often referred to tensile strength is the maximum stress that a material can withstand while being stretched or pulled before fracture. The tensile test for the specimens was conducted according to ASTM.The specimens of size $250 \mathrm{~mm}$ x $25 \mathrm{~mm}$ x $10 \mathrm{~mm}$ were tested with a span length of 250 $\mathrm{mm}$ in tensile mode at a cross head speed of $1 \mathrm{~mm} / \mathrm{min}$.

Ultimate tensile strength $=\{$ Maximum load in N in MPs $\} /\left\{\mathrm{c} / \mathrm{s}\right.$ area in $\mathrm{mm}^{2\}}$

- Young's modulus $(E)=\{$ stress $\} /\{$ strain $\}$ in Gpa

$\circ \operatorname{Stress}(\sigma)=\{\operatorname{load}(\mathrm{P})\} /\{\operatorname{Area}($ bxd $)\}$ in N/mm ${ }^{2}$

$\circ \quad$ Strain $=\{$ Change in length $\} /\{$ Original length $\}$ 
$\mathrm{P}=$ maximum load in $\mathrm{N}, \mathrm{b}=$ width of the specimen in $\mathrm{mm}, \mathrm{d}=$ thickness of the specimen in $\mathrm{mm}$

\section{Result And Discussions}

Tensile Test

Table 4: Ultimate tensile strength of sisal fiber and unsaturated polyester resins.

\begin{tabular}{|c|c|c|c|c|c|}
\hline Samples & $\begin{array}{c}\text { \% wt of sisal } \\
\text { fiber }\end{array}$ & $\begin{array}{c}\text { UTS in } \\
\text { Mpa }\end{array}$ & UTS in Mpa & UTS in Mpa & Avg UTS in Mpa \\
\hline A & 0 & 20.40 & 19.79 & 22.71 & 20.96 \\
\hline B & 5 & 24.92 & 31.84 & 23.91 & 26.89 \\
\hline C & 10 & 27.75 & 31.33 & 38.91 & 32.66 \\
\hline D & 15 & 24.45 & 27.27 & 28.08 & 26.60 \\
\hline E & 20 & 31.94 & 24.76 & 21.30 & 26.00 \\
\hline
\end{tabular}

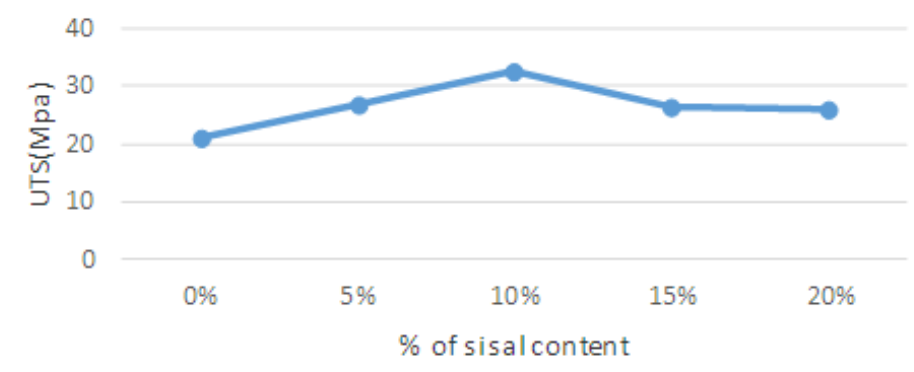

Graph 1: \% wt of sisal vs UTS

Table 5: Ultimate tensile strength of sisal, rice husk and unsaturated polyester resin

\begin{tabular}{|l|l|l|l|l|l|l|}
\hline Samples & $\begin{array}{l}\text { \%wt of Rice } \\
\text { Husk }\end{array}$ & $\begin{array}{l}\text { \%wt of } \\
\text { sisal }\end{array}$ & $\begin{array}{l}\text { UTS in } \\
\text { Mpa }\end{array}$ & $\begin{array}{l}\text { UTS } \\
\text { in } \\
\text { Mpa }\end{array}$ & $\begin{array}{l}\text { UTS in } \\
\text { Mpa }\end{array}$ & $\begin{array}{l}\text { Avg UTS } \\
\text { in } \\
\text { Mpa }\end{array}$ \\
\hline E & 1 & 19 & 15.45 & 18.56 & 20.64 & 18.21 \\
\hline F & 3 & 17 & 19.90 & 15.32 & 18.56 & 17.92 \\
\hline G & 5 & 15 & 20.25 & 15.55 & 17.16 & 17.65 \\
\hline
\end{tabular}

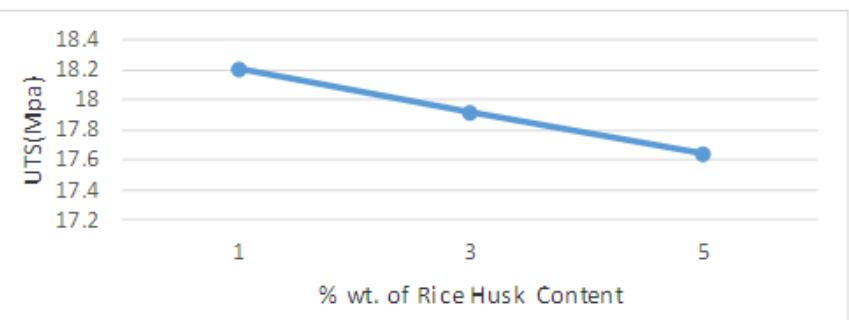

Graph 2: \% wt of sisal, rice husk and resin vs UTS

Bending Test

Table 6: Ultimate Flexural strength of sisal fiber with unsaturated polyester resin

\begin{tabular}{|l|l|l|l|l|l|}
\hline Samples & $\begin{array}{l}\text { \%wt of } \\
\text { Sisal }\end{array}$ & $\begin{array}{l}\text { UTS in } \\
\text { Mpa }\end{array}$ & $\begin{array}{l}\text { UTS in } \\
\text { Mpa }\end{array}$ & $\begin{array}{l}\text { UTS } \\
\text { in } \\
\text { Mpa }\end{array}$ & Avg UFS in Mpa \\
\hline A & 0 & 35.2 & 31.77 & 28.18 & 31.71 \\
\hline B & 5 & 58.95 & 58.31 & 56.73 & 57.99 \\
\hline C & 10 & 35.6 & 40.51 & 50.68 & 42.26 \\
\hline D & 15 & 32.38 & 38.47 & 46.01 & 38.95 \\
\hline E & 20 & 43.32 & 20.27 & 26.88 & 30.15 \\
\hline
\end{tabular}




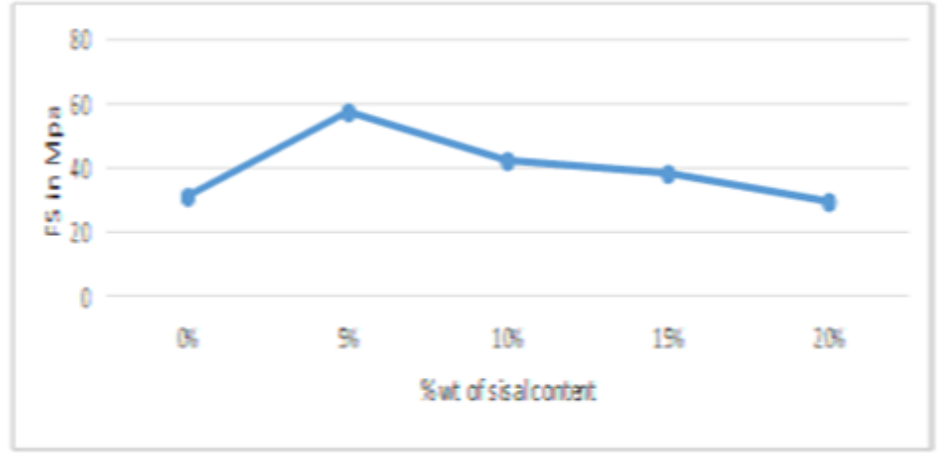

Graph 3: \% wt of sisal vs FS

Flexural Strength $=(3 \mathrm{PL}) /\left(2 \mathrm{BD}^{2}\right) \ldots$...in $\mathrm{MPa}$

Flexural Modulus $=\frac{\mathrm{PL}^{3}}{4 \mathrm{BD}^{3} \delta} \ldots \ldots \ldots . \mathrm{GPa}$

$\mathrm{P}$ - Peak Load in $\mathrm{N},{ }^{4 \mathrm{BD}^{3} \delta}$ tion at load $\mathrm{P}$ in $\mathrm{mm}$

Size of the specimen for flexural test is the $200 \mathrm{~mm} \times 15 \mathrm{~mm} \times 5 \mathrm{~mm}$

Table 7: Ultimate Flexural strength of sisal fiber, rice husk with unsaturated polyester resin

\begin{tabular}{|l|l|l|l|l|l|l|}
\hline Samples & $\begin{array}{l}\text { \%wt of Rice } \\
\text { Husk }\end{array}$ & $\begin{array}{l}\text { \%wt of } \\
\text { sisal }\end{array}$ & $\begin{array}{l}\text { UTS in } \\
\text { Mpa }\end{array}$ & $\begin{array}{l}\text { UTS in } \\
\text { Mpa }\end{array}$ & $\begin{array}{l}\text { UTS in } \\
\text { Mpa }\end{array}$ & $\begin{array}{l}\text { Avg UTS } \\
\text { In Mpa }\end{array}$ \\
\hline E & 1 & 19 & 62.64 & 19.92 & 29.59 & 37.38 \\
\hline F & 3 & 17 & 41.23 & 40.36 & 17.31 & 31.96 \\
\hline G & 5 & 15 & 26.43 & 17.75 & 24.23 & 22.80 \\
\hline
\end{tabular}

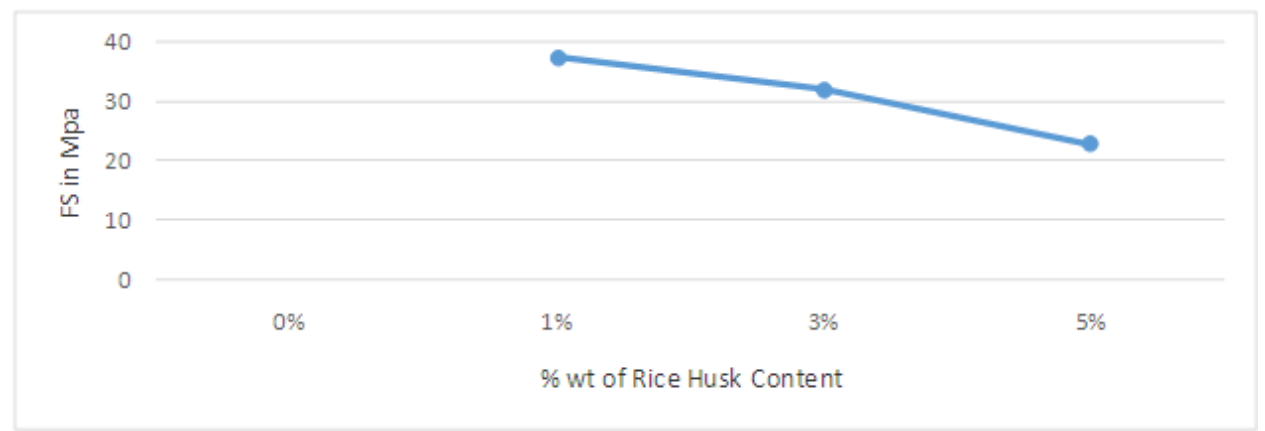

Graph 4: \% wt of sisal vs FS

\section{Hardness Test}

Table 7: Hardness of the Natural fiber reinforced polymer composite

\begin{tabular}{|c|c|c|}
\hline SI.No. & Sample Description & Shore 'D' Hardness \\
\hline 1 & A & $85,85,84$ \\
\hline 2 & B & $86,86,85$ \\
\hline 3 & C & $87,86,87$ \\
\hline 4 & D & $87,87,86$ \\
\hline 5 & E & $86,86,84$ \\
\hline 6 & F & $84,85,84$ \\
\hline 7 & G & $85,85,86$ \\
\hline 8 & H & $84,85,84$ \\
\hline
\end{tabular}

Shore hardness tester is used to determined the hardness of the fiber reinforced polymer composite is shown in table 7. Up to $15 \%$ wt of sisal fiber, the hardness of composite is increased. And $17 \%$ sisal fiber, $3 \%$ rice husk and $80 \%$ of resin for this combination, the hardness is increased. 


\section{Scanning Electron Microstructures:}
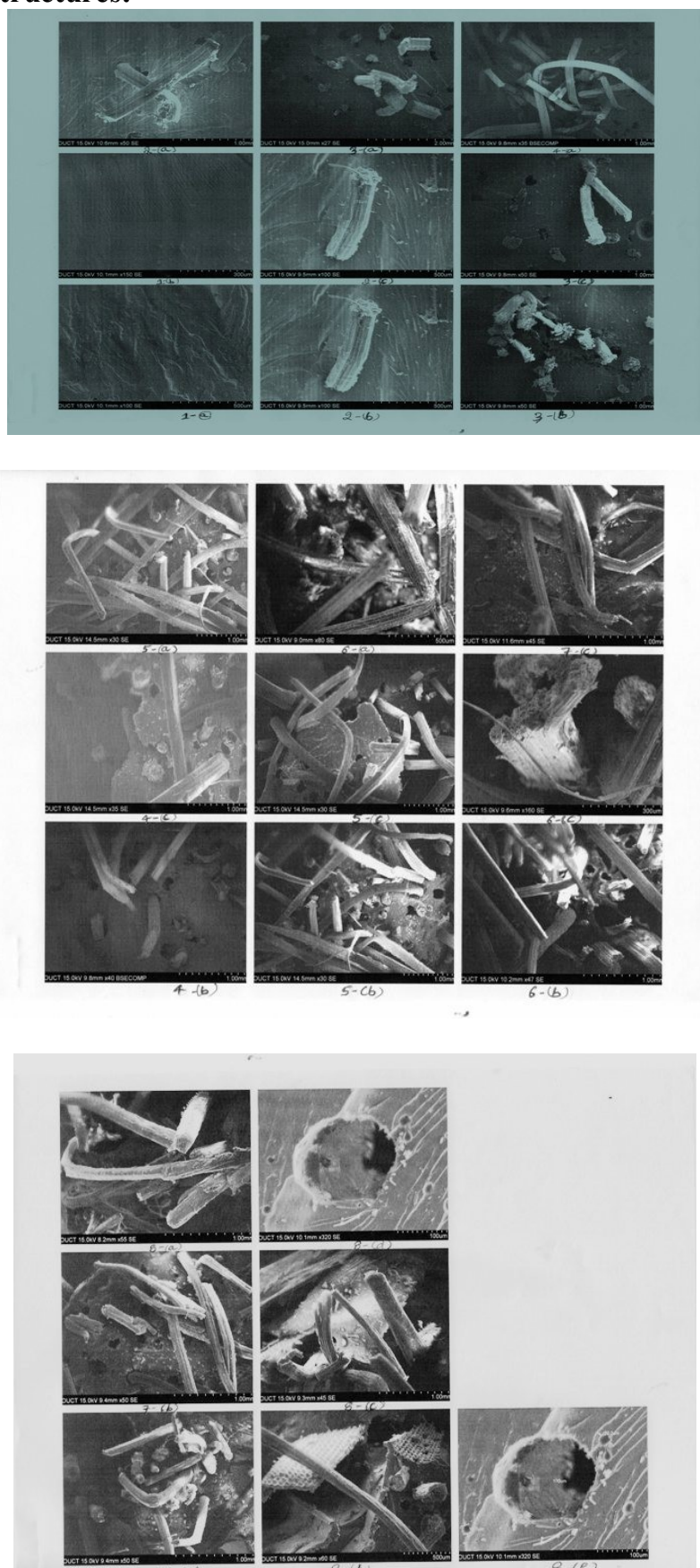

Figure 4: 1(a) and 1(b) is the microstructure of $100 \%$ resin; 2(a),2(b) and 2(c) is the 5\% of sisal fiber and $95 \%$ of resin; 3(a), 3(b) and 3(c) is the $10 \%$ of sisal $+90 \%$ of resin; $4(\mathrm{a}), 4(\mathrm{~b})$ and $4(\mathrm{c})$ is the $15 \%$ of sisal $+90 \%$ resin; $5(a), 5(b)$ and $5(c)$ is the $20 \%$ sisal $+85 \%$ of resin; $6(a), 6(b)$ and $6(c)$ is the $1 \%$ of rice husk $+19 \%$ of sisal fiber $+80 \%$ of resin; $7(\mathrm{a}), 7(\mathrm{~b})$ and $7(\mathrm{c})$ is the $3 \%$ of rice husk $+17 \%$ of sisal fiber $+80 \%$ of resin; $8(\mathrm{a})$, $8(\mathrm{~b}), 8(\mathrm{c}), 8(\mathrm{~d})$ and $8(\mathrm{e})$ is the $5 \%$ of rice husk $+15 \%$ of sisal $+80 \%$ of resin

\section{Conclusion}

In this research, ultimate tensile strength and flexural strength of the natural fiber reinforced polymer composite is increased.

- Ultimate tensile strength of the specimen C (sisal fiber $10 \%+$ resin $80 \%$ ) is $32.66 \mathrm{Mpa}$.

- Ultimate tensile strength of (19\% sisal, $1 \%$ rice husk and $80 \%$ unsaturated polyester resin) the specimen $\mathrm{E}$ is $18.21 \mathrm{Mpa}$.

- Ultimate Flexural strength of sisal fiber, with unsaturated polyester resin B \& C $(5 \%$ \& $10 \%$ of sisal with resin $95 \%$ \& 90\%) is $57.99 \mathrm{Mpa}$ and $42.26 \mathrm{MPa}$. 
- Ultimate Flexural strength of the specimen E (sisal fiber, rice husk with unsaturated polyester resin) is $37.38 \mathrm{MPa}$.

Hardness test:

- $\quad$ specimen $\mathrm{D}(15 \% \mathrm{wt}$ of sisal fiber) hardness of the composite material is 87

- And specimen G (17\% sisal fiber, $3 \%$ rice husk and $80 \%$ of resin) hardness of the composite material is 86

\section{References}

[1]. K. Hardinnawirda and I. SitiRabiatull Aisha, effect of rice husks as filler in polymer matrix composites, Journal of Mechanical Engineering and Sciences, e-ISSN: 2231-8380; Volume 2, pp. 181-186, June 2012, CFKM, University Malaysia Pahang.

[2]. D. Verma1, P.C. Gope, A. Shandilya1, A. Gupta1, and M.K. Maheshwari, Coir Fibre Reinforcement and Application in Polymer Composites: A Review, J. Mater. Environ. Sci. 4 (2) (2013) 263-276, ISSN: 2028-2508 CODEN: JMESCN.

[3]. Vasanta V Cholachagudda 1, Udayakumar P A 2, Ramalingaiah 3, mechanical characterisation of coir and rice husk reinforced hybrid polymer composite, International Journal of Innovative Research in Science, Engineering and Technology (ISO 3297 : 2007 Certified Organization) Vol. 2, Issue 8, August 2013 Copyright to IJIRSET www.ijirset.com 3779.

[4]. K. hardinnawirda and I. sitirabiatull aisha, effect of rice husks as filler in polymer matrix composites, journal of mechanical engineering and sciences (jmes) e-issn: 2231-8380; volume 2, pp. 181-186, June 2012 (C)fm, universiti malaysia Pahang.

[5]. Dr. Navdeep Malhotra1, Khalid Sheikh2 and Dr. Sona Rani3, a review on mechanical characterization of natural fiber reinforced polymer composites, Review Article, Journal of Engineering Research and Studies E-ISSN0976-7916, JERS/Vol.III/ Issue I/January-March, 2012/75-80. 